\title{
OPTIMIZATION OF MACHINING PARAMETERS FOR TURNING OPERATION WITH MULTIPLE QUALITY CHARACTERISTICS USING GREY RELATIONAL ANALYSIS
}

\author{
Franko Puh, Zoran Jurkovic, Mladen Perinic, Miran Brezocnik, Stipo Buljan
}

Original scientific paper

Optimization of machining processes is essential for achieving of higher productivity and high quality products in order to remain competitive. This study investigates multi-objective optimization of turning process for an optimal parametric combination to provide the minimum surface roughness $(R a)$ with the maximum material-removal rate $(M R R)$ using the Grey-Based Taguchi method. Turning parameters considered are cutting speed, feed rate and depth of cut. Nine experimental runs based on Taguchi's $\mathrm{L}_{9}\left(3^{4}\right)$ orthogonal array were performed followed by the Grey relational analysis to solve the multiresponse optimization problem. Based on the Grey relational grade value, optimum levels of parameters have been identified. The significance of parameters on overall quality characteristics of the cutting process has been evaluated by the analysis of variance (ANOVA). The optimal parameter values obtained during the study have been validated by confirmation experiment.

Keywords: ANOVA; Grey relational analysis; multi-objective optimization; Taguchi method; turning

Optimizacija parametara obrade tokarenja s više kriterija kvalitete uporabom Grey relacijske analize

Izvorni znanstveni članak Optimizacija procesa obrade je neophodna za postizanje veće produktivnosti i visoke kvalitete proizvoda kako bi ostali tržišno konkurentni. Ovaj rad istražuje više-kriterijsku optimizaciju procesa tokarenja s optimalnom kombinacijom parametara obrade koji osiguravaju minimalnu hrapavost površine $(R a)$ s maksimalnim učinkom uklanjanja materijala $(M R R)$ uporabom Grey-based Taguchi metode. Razmatrani parametri obrade tokarenjem su brzina rezanja, posmak i dubina rezanja. Primjenom Taguchijevog $\mathrm{L}_{9}\left(3^{4}\right)$ ortogonalnog plana provedeno je devet eksperimenata te je korištena Grey relacijska analiza kako bi se riješio višekriterijski problem optimizacije. Temeljem vrijednosti Grey relacijskog stupnja utvrđene su optimalne razine parametara. Signifikantnost parametara na sveukupne kriterije kvalitete procesa tokarenja ocijenjena je analizom varijance (ANOVA). Optimalne vrijednosti parametara dobivene tijekom istraživanja potvrđene su verifikacijskim eksperimentom.

Ključne riječi: ANOVA; Grey relacijska analiza; Taguchijeva metoda; tokarenje; višekriterijska optimizacija

\section{Introduction}

Determination of optimal machining parameters is continuous engineering task whose goals are to reduce the production costs and to achieve the desired product quality. In turning process, surface quality is one of the most important performance measures. Surface roughness $(R a)$ is a widely used index of product quality and in most cases a technical requirement for mechanical products. Achieving the desired surface quality is of great importance for the functional behavior of a part. At the same time higher material removal rate $(M R R)$ is considered as the factor that directly affects the production cost and the machining hour rate.

In a turning operation, it is an important task to select cutting parameters to achieve high cutting performance for a particular machine and environment. Hence, multiple quality optimization method based on a combination of Grey relational analysis (GRA) and the Taguchi method was used in this paper to determine the optimal values of cutting parameters in order to obtain better surface roughness and increased material removal rate in the finish turning operation. To search for the optimal process condition through a limited number of experimental runs Taguchi's $\mathrm{L}_{9}$ orthogonal array consisting of three factors and three levels was applied to optimize the multiple quality characteristics of the finish turning process.

The three controlling factors, including the cutting speed $(V)$, the depth of cut $(d)$ and feed rate $(f)$, were selected. Grey relational grade is used to convert multi objective problem into a single objective. To identify the optimal combination of process parameters that concurrently minimize the surface roughness $(R a)$ and maximize the material removal rate $(M R R)$ Grey relational analysis was employed. Grey relational analysis (GRA) utilizes a specific concept of information. It defines situations with no information as black, and those with perfect information as white [1]. Additionally, an analysis of variance (ANOVA) was also utilized to examine the most significant influential factors for the $R a$ and $M R R$ in the turning process. Confirmation test was conducted using the optimum cutting parameters determined by the Taguchi optimization method. Based on this analysis, valuable remarks about presented optimization approach are pointed out in the conclusion of this study. Many researchers have studied the effects of optimal selection of machining parameters in turning.

Tzeng and Chen [2] used grey relational analysis to optimize the process parameters in turning of tool steels. They performed Taguchi experiments with eight independent variables, the optimum turning parameters were determined based on grey relational grade which maximizes the accuracy and minimizes the surface roughness and dimensional precision.

Sahoo et al. [3] have used Grey relational analysis to perform multi-objective optimization of surface roughness and MRR in turning of AA 1040 steel and determined that cutting speed is the most influencing parameter affecting combined Grey relational grade followed by depth of cut and feed rate.

Tzeng et al. [4] have used Grey relational analysis to perform optimization of turning operations with multiple performance characteristics such as roughness average, roughness maximum, and roundness. The depth of cut was identified to be the most influencing parameter 
affecting the Grey relational grade followed by cutting speed and feed rate.

Similarly, the researchers have applied the Grey relational analysis (GRA) to different processes with multiple performance characteristics and greatly improved through this approach. Tosun [5] investigated optimization of drilling parameters to minimize surface roughness and burr height, Chang and $\mathrm{Lu}$ [6] investigated optimization of cutting parameters for side milling operations, Datta et al. [7] investigated optimization of bead geometry in submerged arc welding process, Chakradhar and Gopal [8] investigated optimization of electrochemical machining of EN31 steel, etc. In the recent times researchers have also tried to optimize the machining parameters using various methods like Genetic Algorithm, Particle swarm optimization, ANN, Simulated annealing method, Multi-Objective Evolutionary Algorithm, etc. $[9 \div 12]$.

\section{Experimental procedure \\ 2.1 Machining conditions}

Experimental research was performed on lathe machine "Georg Fisher NDM-16". Test samples were carbon steel bars DIN Ck45 with $100 \mathrm{~mm}$ in diameter and $380 \mathrm{~mm}$ in length. Chemical composition and mechanical properties of DIN Ck45 steel are given in Tab. 1 and Tab. 2. Experiments were carried out by the external machining turning tool with the holder mark DDJNL $3225 \mathrm{P} 15$ and the coated inserts type DNMG 150608PM4025 under dry cutting conditions. The tool geometry was: rake angle $17^{\circ}$, clearance angle $5^{\circ}$, main cutting edge $93^{\circ}$ with nose radius $0,8 \mathrm{~mm}$. Before each cut, the insert was changed to eliminate the effect of toolwear. Surface roughness measurements were performed with SurftestMitutoyo SJ-201P. The surface roughness measured in the paper is the arithmetic mean deviation of surface roughness of profile $R a[13 \div 15]$. The material removal rate of the work piece is the volume of the material removed per minute. It can be calculated using the following equation:

$M R R=V f d$,

where three main cutting parameters are cutting speed $V$ $(\mathrm{m} / \mathrm{min})$, feed rate $f(\mathrm{~mm} / \mathrm{r})$ and depth of cut $d(\mathrm{~mm})$.

Table 1 Chemical composition of carbon steel Ck45 (wt\%)

\begin{tabular}{|c|c|c|c|c|c|c|c|}
\hline Element & $\mathrm{C}$ & $\mathrm{Si}$ & $\mathrm{Mn}$ & $\mathrm{P}$ & $\mathrm{S}$ & $\mathrm{Ni}$ & $\mathrm{Mo}$ \\
\hline Content & 0,467 & 0,309 & 0,657 & 0,014 & 0,021 & 0,039 & 0,0087 \\
\hline
\end{tabular}

Table 2 Mechanical properties of carbon steel Ck45

\begin{tabular}{|c|c|c|c|c|}
\hline Material & $\begin{array}{c}\text { Tensile } \\
\text { strength } \\
(\mathrm{MPa})\end{array}$ & $\begin{array}{c}\text { Yield } \\
\text { strength } \\
(\mathrm{MPa})\end{array}$ & $\begin{array}{c}\% \text { of } \\
\text { Elongation }\end{array}$ & $\begin{array}{c}\text { Hardness } \\
(\mathrm{HB})\end{array}$ \\
\hline $\mathrm{Ck} 45$ & 650 & 420 & 24,2 & 179 \\
\hline
\end{tabular}

\subsection{Design of experiments}

The Taguchi method uses a special design of orthogonal arrays to study the entire parameter space with a limited number of experiments [16]. The experiments have been carried out by using the standardized Taguchi- based experimental design, a $\mathrm{L}_{9}\left(3^{4}\right)$ orthogonal arrays, with three levels (coded by: 1;2 and 3) of three main cutting parameters, namely, cutting speed $V$, feed rate $f$ and depth of cut $d$ (shown in Tab. 3).

Table 3 Cutting parameters and their limits

\begin{tabular}{|c|c|c|c|c|}
\hline \multirow{2}{*}{ Symbol } & Parameters & \multicolumn{3}{|c|}{ Levels } \\
\cline { 2 - 5 } & $\begin{array}{c}\text { Coding - orthogonal } \\
\text { array }\end{array}$ & 1 & 2 & 3 \\
\hline $\mathrm{A}$ & $X_{1}=V(\mathrm{~m} / \mathrm{min})$ & 400 & 450 & 500 \\
\hline $\mathrm{B}$ & $X_{2}=f(\mathrm{~mm} / \mathrm{rev})$ & 0,1 & 0,15 & 0,2 \\
\hline $\mathrm{C}$ & $X_{3}=d(\mathrm{~mm})$ & 0,4 & 0,8 & 1,2 \\
\hline
\end{tabular}

The necessary number of test runs is nine. The last column (for the fourth factor) in the $\mathrm{L}_{9}\left(3^{4}\right)$ orthogonal array is left empty for this specific study. The experimental results and the Taguchi $\mathrm{L}_{9}\left(3^{4}\right)$ orthogonal array are shown in Tab. 4.

Table 4 Orthogonal array $\mathrm{L} 9\left(3^{4}\right)$ of the experimental runs and results

\begin{tabular}{|c|c|c|c|c|c|}
\hline $\begin{array}{c}\text { Exp. } \\
\text { No. }\end{array}$ & $\mathrm{A}$ & $\mathrm{B}$ & $\mathrm{C}$ & \multirow{2}{*}{$R(\mu \mathrm{m})$} & $\begin{array}{c}M R R \\
\left(\mathrm{~cm}^{3} / \mathrm{min}\right)\end{array}$ \\
\cline { 2 - 4 } & $V$ & $f$ & $d$ & 0,77 & 16 \\
\hline 1. & 1 & 1 & 1 & 1,33 & 48 \\
\hline 2. & 1 & 2 & 2 & 2,14 & 96 \\
\hline 3. & 1 & 3 & 3 & 1,11 & 36 \\
\hline 4. & 2 & 1 & 2 & 1,13 & 81 \\
\hline 5. & 2 & 2 & 3 & 2,01 & 36 \\
\hline 6. & 2 & 3 & 1 & 1,19 & 60 \\
\hline 7. & 3 & 1 & 3 & 1,05 & 30 \\
\hline 8. & 3 & 2 & 1 & 1,93 & 80 \\
\hline 9. & 3 & 3 & 2 & & \\
\hline
\end{tabular}

\section{Results and discussions \\ 3.1 Grey relational analysis}

Grey relational analysis was proposed by Deng in 1989 [17] and it is widely used for measuring the degree of relationship between sequences by Grey relational grade [18].

By employing Grey relational analysis associated with the Taguchi method, optimization of the complicated multi-response characteristics can be converted into optimization of a single response characteristic with Grey relational grade as an objective function.

In the present work the objectives are to minimize the surface roughness and maximize the $M R R$ of finish turning process. Thus, surface roughness and material removal rate as the multi-responses are combined by Grey relational grade using Grey relational analysis.

\subsection{Grey relational generation}

In Grey relational analysis the first step is to perform the Grey relational generation in which the results of the experiments are normalized in the range between 0 and 1 due to different measurement units. Data pre-processing converts the original sequences to a set of comparable sequences. Normalizing the experimental data for each quality characteristic is done according to the type of performance response. Thus, the normalized data processing for $\mathrm{Ra}$ corresponding to smaller-the-better criterion can be expressed as: 


$$
x_{i}(k)=\frac{\max y_{i}(k)-y_{i}(k)}{\max y_{i}(k)-\min y_{i}(k)},
$$

The normalized data processing for $M R R$ corresponding to larger-the-better criterion can be expressed as:

$$
x_{i}(k)=\frac{y_{i}(k)-\min y_{i}(k)}{\max y_{i}(k)-\min y_{i}(k)},
$$

where, $i=1,2,3, \ldots, m, m$ is the number of experimental runs in Taguchi orthogonal array, in the present work $\mathrm{L}_{9}$ orthogonal array is selected then $m=9 . k=1,2, \ldots, n, n$ is the number of quality characteristics or process responses, in the present work surface roughness and material removal rate are selected, then $n=2$.

Min $y_{\mathrm{i}}(k)$ is the smallest value of $y_{\mathrm{i}}(k)$ for the $k^{\text {th }}$ response. Max $y_{\mathrm{i}}(k)$ is the largest value of $y_{\mathrm{i}}(k)$ for the $k^{\text {th }}$ response. $x_{\mathrm{i}}(k)$ is the value after Grey relational generation. The normalized values of surface roughness and material removal rate calculated by Eq. (2) and (3) are shown in Tab. 5.

Table 5 Normalized values and deviation sequences of responses

\begin{tabular}{|c|c|c|c|c|}
\hline \multirow{2}{*}{$\begin{array}{c}\text { Exp. } \\
\text { No. }\end{array}$} & \multicolumn{2}{|c|}{$\begin{array}{c}\text { Normalized values of } \\
\text { responses }\end{array}$} & \multicolumn{2}{c|}{ Deviation sequences $\Delta_{0 \mathrm{i}}(k)$} \\
\cline { 2 - 3 } & $R a$ & $M R R$ & \multirow{2}{*}{$R a$} & $M R R$ \\
\cline { 2 - 3 } & $\begin{array}{c}\text { Smaller- } \\
\text { the-better }\end{array}$ & $\begin{array}{c}\text { Larger-the- } \\
\text { better }\end{array}$ & & \\
\hline 1. & 1,0000 & 0,0000 & 1,0000 & 1,0000 \\
\hline 2. & 0,5912 & 0,4000 & 0,0000 & 0,6000 \\
\hline 3. & 0,0000 & 1,0000 & 0,4088 & 0,0000 \\
\hline 4. & 0,7518 & 0,2500 & 1,0000 & 0,7500 \\
\hline 5. & 0,7372 & 0,8125 & 0,2482 & 0,1875 \\
\hline 6. & 0,0948 & 0,2500 & 0,2628 & 0,7500 \\
\hline 7. & 0,6934 & 0,5500 & 0,9051 & 0,4500 \\
\hline 8. & 0,7956 & 0,1750 & 0,3066 & 0,8250 \\
\hline 9. & 0,1532 & 0,8000 & 0,2044 & 0,2000 \\
\hline
\end{tabular}

\subsection{Grey relational coefficient and Grey relational grade}

The second step is to calculate the Grey relational coefficient based on the normalized experimental data to represent the correlation between the desired and actual experimental data. The overall Grey relational grade is then computed by averaging the Grey relational coefficient corresponding to each performance characteristic. As a result, optimal combination of process parameters is evaluated considering the highest Grey relational grade by using the Taguchi method. Based on the normalized experimental data the Grey relation coefficient can be calculated using the following equations:

$$
\begin{aligned}
& \xi_{i}(k)=\frac{\Delta_{\min }+\varsigma \Delta_{\max }}{\Delta_{0 i}(k)+\varsigma \Delta_{\max }}, \\
& \Delta_{0 i}(k)=\left\|x_{0}(k)-x_{i}(k)\right\|, \\
& \Delta_{\max }=\max _{\forall j \in i} \max _{\forall k}\left\|x_{0}(k)-x_{i}(k)\right\|, \\
& \Delta_{\min }=\min _{\forall j \in i} \min _{\forall k}\left\|x_{0}(k)-x_{i}(k)\right\|,
\end{aligned}
$$

where $\Delta_{o i}=\left\|x_{0}(k)-x_{\mathrm{i}}(k)\right\|$ is difference of the absolute value between $x_{0}(k)$ and $x_{\mathrm{i}}(k), x_{0}(k)$ is the reference sequence of the $k^{\text {th }}$ quality characteristics.

$\Delta_{\min }$ and $\Delta_{\max }$ are respectively the minimum and maximum values of the absolute differences $\left(\Delta_{o i}\right)$ of all comparing sequences.

$\zeta$ is a distinguishing coefficient, $0 \leq \zeta \leq 1$, the purpose of which is to weaken the effect of $\Delta_{\max }$ when it gets too big and thus enlarges the difference significance of the relational coefficient. In the present case, $\zeta=0,5$ is used due to the moderate distinguishing effects and good stability of outcomes.

The Grey relation coefficient of each performance characteristic is shown in Tab. 6. After averaging the Grey relational coefficients, the Grey relational grade $\gamma_{i}$ can be calculated as follows:

$\gamma_{i}=\frac{1}{n} \sum_{k=1}^{n} \xi_{i}(k)$

where, $i=1,2,3 \ldots 9$, ( $\mathrm{L}_{9}$ orthogonal array is selected), $\xi_{\mathrm{i}}(k)$ is the Grey relational coefficient of $k^{\text {th }}$ response in $i^{\text {th }}$ experiment and $n$ is the number of responses. The optimum level of the process parameters is the level with the highest Grey relational grade.

The higher value of the Grey relational grade corresponds to an intense relational degree between the reference sequence $x_{0}(k)$ and the given sequence $x_{\mathrm{i}}(k)$. The Grey relational coefficients and Grey relational grade are presented in Tab. 6 calculated by Eq. (4) and (8), respectively. The highest Grey relational grade is the rank

\begin{tabular}{|c|c|c|c|c|c|}
\hline \multirow{2}{*}{$\begin{array}{l}\text { Exp. } \\
\text { No. }\end{array}$} & \multicolumn{2}{|c|}{$\begin{array}{c}\text { Grey relational } \\
\text { coefficient }\end{array}$} & \multirow{2}{*}{$\begin{array}{l}\text { Grey } \\
\text { relational } \\
\text { grade }\end{array}$} & \multirow{2}{*}{ Rank } & \multirow{2}{*}{$\begin{array}{c}S / N \text { Ratio } \\
\text { Larger-the- } \\
\text { better }\end{array}$} \\
\hline & $R a$ & $M R R$ & & & \\
\hline 1. & 1,0000 & 0,3333 & 0,66667 & 3 & $-3,5218$ \\
\hline 2. & 0,5502 & 0,4545 & 0,50237 & 8 & $-5,9795$ \\
\hline 3. & 0,3333 & 1,0000 & 0,66667 & 2 & $-3,5218$ \\
\hline 4. & 0,6683 & 0,4000 & 0,53415 & 7 & $-5,4468$ \\
\hline 5. & 0,6555 & 0,7273 & 0,69139 & 1 & $-3,2056$ \\
\hline 6. & 0,3558 & 0,4000 & 0,37792 & 9 & $-8,4520$ \\
\hline 7. & 0,6199 & 0,5263 & 0,57311 & 4 & $-4,8352$ \\
\hline 8. & 0,7098 & 0,3774 & 0,54360 & 5 & $-5,2944$ \\
\hline 9. & 0,3713 & 0,7143 & 0,54278 & 6 & $-5,3075$ \\
\hline
\end{tabular}
of 1 . Therefore, the experiment number 5 is the best combination of turning parameters for surface roughness and material removal rate among the nine experiments.

Table 6 Grey relational coefficient, Grey relational grade and corresponding $S / N$ ratios

The multi-objective optimization problem has been transformed into a single equivalent objective function optimization problem using Grey relational analysis. Accordingly, optimal combination of process parameters is evaluated considering the highest Grey relational grade by using the Taguchi method.

\subsection{Analysis of $S / N$ ratios}

Taguchi method recommends the use of the $S / N$ ratio to measure the quality characteristics deviating from the desired values [19]. The signal-to-noise $(S / N)$ ratio is a 
measure of the magnitude of a data set relative to the standard deviation. In the Taguchi method, signal to-noise $S / N$ ratio is used to represent a performance characteristic and the largest value of $S / N$ ratio means the optimal level of the turning parameters.

There are three types of $S / N$ ratio: the larger-thebetter, the nominal-the better, and the smaller-the-better. Tab. 6 shows the $S / N$ ratio based on the larger-the-better criterion for the overall Grey relational grade calculated using Eq. (9):

$$
S / N=-10 \log \left[\frac{1}{n} \sum_{i=1}^{n} \frac{1}{y_{i}^{2}}\right],
$$

where $n$ is the number of measurements, and $y_{i}$ is the measured characteristic value. The mean response for the Grey relational grade with its grand mean and the main effect plot of the Grey relational grade are very important because the optimal process condition can be evaluated from this plot, (shown in Fig. 1. and 2.). The dashed line is the value of the total mean of the $S / N$ ratio and mean effect plot.

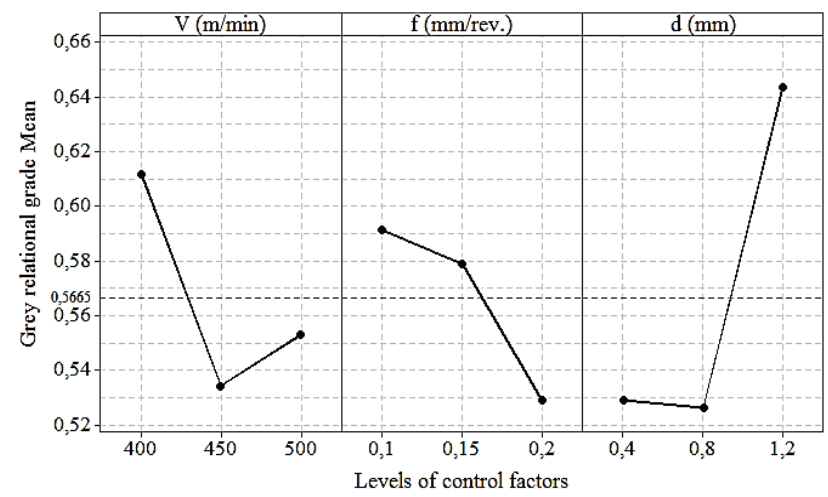

Figure 1 Mean plot for the Grey relational grade

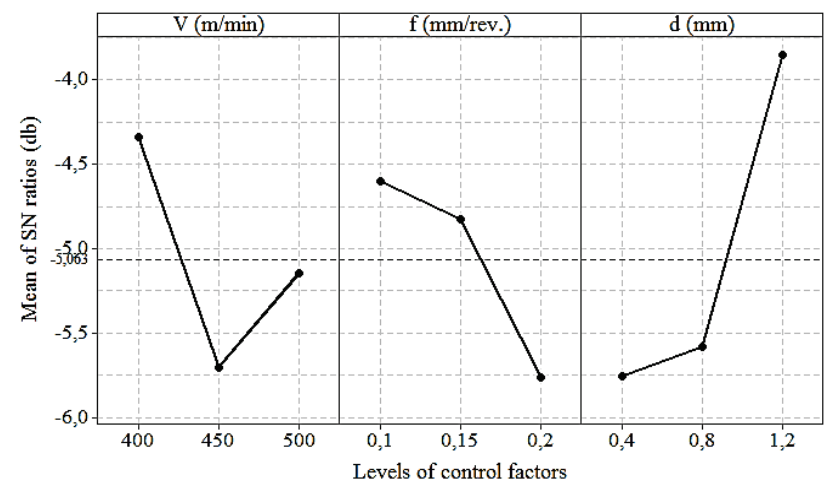

Figure $2 \mathrm{~S} / \mathrm{N}$ plot for the Grey relational grade

The means of the Grey relational grade for each level of turning parameters were calculated from Tab. 6 and summarized in Tab. 7. The larger the Grey relational grade, the better the multiple quality characteristics.

Table 7 Response table for the mean Grey relational grade

\begin{tabular}{|c|c|c|c|c|}
\hline \multirow{2}{*}{ Parameter } & \multicolumn{4}{|c|}{ Grey relational grade } \\
\cline { 2 - 5 } & Level 1 & Level 2 & Level 3 & Delta \\
\hline A $(V)$ & $\mathbf{0 , 6 1 1 9}$ & 0,5345 & 0,5532 & 0,0774 \\
\hline B $(f)$ & $\mathbf{0 , 5 9 1 3}$ & 0,5791 & 0,5291 & 0,0622 \\
\hline C $(d)$ & 0,5294 & 0,5264 & $\mathbf{0 , 6 4 3 7}$ & 0,1173 \\
\hline
\end{tabular}

Total mean value of the Grey relational grade $=\mathbf{0 , 5 6 6 5}$
As indicated in Fig. 1. and 2., the optimal parameter condition for turning of the $\mathrm{C} 45$ carbon steel regarding surface roughness and material removal rate multiple performance characteristics are levels: A-level 1, B-level 1, C-level 3. Namely, cutting speed of $V=400 \mathrm{~m} / \mathrm{min}$, feed rate of $f=0,1 \mathrm{~mm} / \mathrm{rev}$ and depth of cut $d=1,2 \mathrm{~mm}$.

\subsection{Analysis of variance (ANOVA)}

The purpose of the analysis of the variance (ANOVA) is to investigate which turning parameters significantly affect the quality characteristic. By using the Grey relational grade value, ANOVA is indicated for identifying the significant factors. In addition to degree of freedom $(D F)$, mean of squares $(M S)$, sum of squares $(S S), F$-ratio and contribution $(C)$ associated with each factor was presented. The higher the percentage contribution was, the more important the factor was for affecting the performance characteristics. The results of ANOVA for the Grey grade values are represented in Tab. 8. The results of the ANOVA indicate that the percentage contribution of cutting speed $(V)$, feed rate $(f)$ and the depth of cut $(d)$ influencing the multiple performance characteristics were $12,63 \%, 8,41 \%$ and $34,62 \%$, respectively. From the percentage contribution of the ANOVA, the cutting speed and depth of cut were two parameters significantly influencing the Grey relational grade. And the depth of cut was the most effective factor on the performance.

\subsection{Confirmation experiment}

After the optimal level of turning parameters has been identified, a verification test needs to be carried out in order to check the accuracy of analysis. The estimated Grey relational grade $\hat{\gamma}$ is used to predict the improvement of the performance characteristic by using optimum combination of turning parameters. The estimated Grey relational grade $\hat{\gamma}$ can be calculated as:

$\hat{\gamma}=\gamma_{m}+\sum_{i=1}^{o}\left(\bar{\gamma}_{i}-\gamma_{m}\right)$

here $\gamma_{\mathrm{m}}$ is the total mean Grey relational grade, $\bar{\gamma}_{i}$ is the mean Grey relational grade at the optimal level, and $o$ is the number of the machining parameters significantly affect the multiple performance characteristics.

The A1B1C3 was an optimal combination of turning parameters by the Grey relational analysis. Therefore, the A1B1C3 optimal combination parameters were regarded as the confirmation test.

Tab. 9 shows the comparison of the estimated Grey relational grade with the actual Grey relational grade obtained in verification experiment using the optimal cutting parameters. Namely, surface roughness $R a$ was improved from $2,01 \mu \mathrm{m}$ to $1,11 \mu \mathrm{m}$ and the material removal rate $M R R$ was also improved from $36 \mathrm{~cm}^{3} / \mathrm{min}$ to $48 \mathrm{~cm}^{3} / \mathrm{min}$ considering initial cutting conditions. In conclusion, it is clearly shown that the multiple performance characteristics in turning $\mathrm{C} 45$ carbon steel were significantly improved by increase in Grey relational grade of 0,1835 . 
Table 8 ANOVA results of turning process parameters

\begin{tabular}{|l|c|c|c|c|c|c|}
\hline \multicolumn{1}{|c|}{ Main control factors } & Symbol & $\begin{array}{c}\text { Degree of freedom } \\
D F\end{array}$ & $\begin{array}{c}\text { Sum of squares } \\
(S S)\end{array}$ & $\begin{array}{c}\text { Mean of squares } \\
(M S)\end{array}$ & $F$-ratio & $\begin{array}{c}\text { Contribution, } \\
C(\%)\end{array}$ \\
\hline Cutting speed $V$ & A & 2 & 0,009792 & 0,004896 & 0,28 & 12,63 \\
\hline Feed rate $f$ & B & 2 & 0,006515 & 0,003258 & 0,19 & 8,41 \\
\hline Depth of cut $d$ & C & 2 & 0,026836 & 0,013418 & 0,78 & 34,62 \\
\hline Error & - & 2 & 0,034371 & 0,017186 & - & 44,34 \\
\hline Total & - & 8 & 0,077515 & - & - & 100 \\
\hline
\end{tabular}

Table 9 Results of confirmation test

\begin{tabular}{|c|c|c|c|}
\hline \multicolumn{4}{|c|}{ Optimal process condition } \\
\hline & & Prediction & Experiment \\
\hline Factor levels & $\mathrm{A} 2 \mathrm{~B} 3 \mathrm{C} 1$ & A1B1C3 & A1B1C3 \\
\hline$R a(\mu \mathrm{m})$ & 2,01 & - & 1,11 \\
\hline$M R R\left(\mathrm{~cm}^{3} / \mathrm{min}\right)$ & 36 & - & 48 \\
\hline$S / N$ ratio of overall Grey relational grade & $-8,4520$ & $-2,67106$ & $-5,01424$ \\
\hline Overall Grey relational grade & $\mathbf{0 , 3 7 7 9 2}$ & $\mathbf{0 , 7 1 3 8 9 8}$ & 0,56142 \\
\hline
\end{tabular}

\section{Conclusions}

In this study, the Grey-based Taguchi method was applied for the multiple performance characteristics of turning operations.

Multi-response optimization of turning process has been used to obtain optimal parametric combination that provides the minimum surface roughness $(R a)$ with the maximum material-removal rate $(M R R)$. The application of the Grey relational analysis based on the Taguchi method directly integrates the multiple quality characteristics into a single performance characteristic called Grey relational grade. Optimal combination of process parameters is evaluated considering the highest Grey relational grade by using the Taguchi method.

By applying the Taguchi method the number of experiments is drastically reduced. $\mathrm{A} \mathrm{L}_{9}\left(3^{4}\right)$ Taguchi orthogonal array, the signal to noise $(S / N)$ ratio and the analysis of variance (ANOVA) were used for the optimization of cutting parameters considering Grey relational grade. According to the analysis the optimal parameter combination for turning of the $\mathrm{C} 45$ carbon steel regarding surface roughness and material removal rate multiple performance characteristics were levels: A-level 1, B-level 1, and C-level 3. Namely, cutting speed of $V=$ $400 \mathrm{~m} / \mathrm{min}$, feed rate of $f=0,1 \mathrm{~mm} / \mathrm{rev}$ and depth of cut $d$ $=1,2 \mathrm{~mm}$.

The results of the ANOVA indicate that the percentage contribution of cutting speed, feed rate and the depth of cut influencing the multiple performance characteristics were 12,63\%, 8,41 \% and 34,62 \%, respectively. From the percentage contribution of the ANOVA, the cutting speed and depth of cut were two parameters significantly influencing the Grey relational grade. And the depth of cut was the most effective factor on the performance.

Effectiveness of this method was verified by the test experiment. The Grey relational grade of the multiple performance characteristics was significantly improved by 0,1835 through this method. Namely, surface roughness $R a$ was improved from $2,01 \mu \mathrm{m}$ to $1,11 \mu \mathrm{m}$ and the material removal rate $M R R$ was improved from 36 $\mathrm{cm}^{3} / \mathrm{min}$ to $48 \mathrm{~cm}^{3} / \mathrm{min}$ considering initial cutting conditions.
Therefore, the optimization of the complicated multiple performance characteristics of the processes can be greatly simplified by using the Grey-based Taguchi method. The performance characteristics of the turning operations, such as the material removal rate and the surface roughness are greatly enhanced by using this method.

\section{Acknowledgments}

The work was supported by the Federal Ministry of Education and Science of Bosnia and Herzegovina through grant No. 01-2440/13 and by the University of Rijeka through grant No. 13.09.1.2.10.

\section{References}

[1] Chan, J. W. K.; Tong, T. K. L. Multi-criteria material selections and end-of-life product strategy: Grey relational analysis approach. // Materials \& Design. 28, 5(2007), pp. 1539-1546. DOI: 10.1016/j.matdes.2006.02.016

[2] Tzeng, Y. F.; Chen, F. C. Multiobjective process optimisation for turning of tool steels. // International Journal of Machining and Machinability of Materials. 1, 1(2006), pp. 76-93. DOI: 10.1504/IJMMM.2006.010659

[3] Sahoo, A. K.; Baral, A. N.; Rout, A. K.; Routra, B. C. Multi-objective optimization and predictive modelling of surface roughness and material removal rate in turning using Grey Relational and Regression Analysis. // Procedia Engineering. $38, \quad(2012)$, pp. 1606-1627. DOI: 10.1016/j.proeng.2012.06.197

[4] Tzeng, C. J.; Lin, Y. H.; Yang, Y. K.; Jeng, M. C. Optimization of turning operations with multiple performance characteristics using the Taguchi method and Grey relational analysis. // Journal of Materials Processing Technology. 209, 6(2009), pp. 2753-2759. DOI: 10.1016/j.jmatprotec.2008.06.046

[5] Tosun, N. Determination of optimum parameters for multiperformance characteristics in drilling by using grey relational analysis. // International Journal of Advanced Manufacturing Technology. 28, 5-6(2006), pp. 450-455. DOI: $10.1007 / s 00170-004-2386-y$

[6] Chang, C. K.; Lu, H. S. Design optimization of cutting parameters for side milling operations with multiple performance characteristics. // International Journal of Advanced Manufacturing Technology. 32, 1-2(2007), pp. 18-26. DOI: 10.1007/s00170-005-0313-5 
[7] Datta, S.; Bandyopadhyay, A.; Pal, P. K. Grey-based Taguchi method for optimization of bead geometry in submerged arc bead-on-plate welding. // International Journal of Advanced Manufacturing Technology. 39, 1112(2008), pp. 1136-1143. DOI: 10.1007/s00170-007-1283-6

[8] Chakradhar, D.; Venu Gopal, A. Multi-objective optimization of electrochemical machining of EN31 steel by grey relational analysis. // International Journal of Modeling and Optimization. 1, 2(2011), pp. 113-117. DOl: 10.7763/IJMO.2011.V1.20

[9] Hrelja, M.; Klancnik, S.; Irgolic, T.; Paulic, M.; Jurkovic, Z.; Balic, J.; Brezocnik, M. Particle swarm optimization approach for modelling a turning process. // Advances in Production Engineering \& Management. 9, 1(2014), pp. 2130. DOI: 10.14743/apem2014.1.173

[10] Hrelja M.; Klancnik S.; Balic J.; Brezocnik M. Modelling of a Turning Process Using the Gravitational Search Algorithm. // International Journal of Simulation Modelling. 13, 1(2014), pp. 30-41. DOl: 10.2507/IJSIMM13(1)3.248

[11] Cus, F.; Zuperl, U. Surface Roughness Control Simulation of Turning Processes. // Strojniski vestnik - Journal of Mechanical Engineering. 61, 4(2015), pp. 245-253. DOI:10.5545/sv-jme.2014.2345

[12] Senthilkumar, N.; Tamizharasan, T.; Anandakrishnan, V. An ANN approach for predicting the cutting inserts performances of different geometries in hard turning. // Advances in Production Engineering \& Management. 8, 4(2013), pp. 231-241. DOI: 10.14743/apem2013.4.170

[13] Saric, T.; Simunovic, G.; Simunovic, K. Use of Neural Networks in Prediction and Simulation of Steel Surface Roughness. // International Journal of Simulation Modelling. $\quad 12, \quad 4(2013), \quad$ pp. 225-236. DOI: 10.2507/IJSIMM12(4)2.241

[14] Jurkovic, Z.; Cukor, G.; Andrejcak, I. Improving the surface roughness at longitudinal turning using the different optimization methods. // Technical Gazette. 17, 4(2010), pp. 397-402.

[15] Simunovic G.; Simunovic K.; Saric T. Modelling and Simulation of Surface Roughness in Face Milling. // International Journal of Simulation Modelling. 12, 3(2013), pp. 141-153. DOI: 10.2507/IJSIMM12(3)1.219

[16] Puh, F.; Segota, T.; Jurkovic, Z. Optimization of hard turning process parameters with PCBN tool based on the Taguchi method. // Technical Gazette. 19, 2(2012), pp. 415419.

[17] Deng, J. Introduction to grey system theory. // Journal of Grey System. 1, 1(1989), pp. 1-24.

[18] Senthilkumar, N.; Sudha, J.; Muthukumar, V. A grey-fuzzy approach for optimizing machining parameters and the approach angle in turning AISI 1045 steel. // Advances in Production Engineering \& Management, 10, 4(2015), pp. 195-208. DOI: 10.14743/apem2015.4.202.

[19] Montgomery, D. Design and Analysis of Experiments. $5^{\text {th }}$ ed. New York: John Wiley \& Sons, Inc., 2003.

\section{Authors' addresses}

Franko Puh

Uljanik Strojogradnja d.d.

Flaciusova 1, p.p. 114, HR-52100 Pula, Croatia

E-mail: franko.puh@uljanik.hr

Assoc. Prof. Zoran Jurkovic, Ph.D.

Department of Industrial Engineering and Management, Faculty of Engineering, University of Rijeka, Vukovarska 58, HR-51000 Rijeka, Croatia

E-mail: zoran.jurkovic@riteh.hr

Full. Prof. Mladen Perinic, Ph.D.

Department of Industrial Engineering and Management, Faculty of Engineering, University of Rijeka, Vukovarska 58, HR-51000 Rijeka, Croatia E-mail: mladen.perinic@riteh.hr

Full. Prof. Miran Brezocnik, Ph.D.

Production Engineering Institute,

Faculty of Mechanical Engineering, University of Maribor Smetanova 17, SI-2000 Maribor, Slovenia

E-mail: miran.brezocnik@um.si

Assist. Prof. Stipo Buljan, Ph.D.

Federal Ministry of Energy, Mining and Industry, A. Šantića bb, BA-88000 Mostar, Bosnia and Herzegovina E-mail: stipo.buljan@tel.net.ba 